\title{
Delays during PBMC isolation have a moderate effect on yield, but severly compromise cell viability
}

Golke $\mathrm{T}^{1 *}$, Mucher $\mathrm{P}^{2} *$, Schmidt $\mathrm{P}^{2}$, Radakovics $\mathrm{A}^{2}$, Repl $\mathrm{M}^{2}$, Hofer $\mathrm{P}^{2}$, Perkmann $\mathrm{T}^{2}$, Fondi $\mathrm{M}^{1}$,

Schmetterer $\mathrm{KG}^{2} *$ \& Haslacher $\mathrm{H}^{2} *$

*these authors contributed equally

${ }^{1}$ FH Campus Wien, University of Applied Sciences, Vienna, Austria

${ }^{2}$ Department of Laboratory Medicine, Medical University of Vienna, Vienna, Austria

\section{Please address all correspondence to:}

Priv. Doz. Mag. DDr. Helmuth Haslacher, BSc BA

Medical University of Vienna

Department of Laboratory Medicine

Waehringer Guertel 18-20

A-1090 Vienna, Austria

helmuth.haslacher@meduniwien.ac.at

Phone: +431 40400 53190, Fax: +431 4049515547

NOTE: This preprint reports new research that has not been certified by peer review and should not be used to guide clinical practice. 16 
medRxiv preprint doi: https://doi.org/10.1101/2022.01.02.22268625; this version posted January 3, 2022. The copyright holder for this preprint (which was not certified by peer review) is the author/funder, who has granted medRxiv a license to display the preprint in perpetuity.

\section{Abstract}

\section{Background:}

Peripheral blood mononuclear cells (PMBCs) are a versatile material for clinical routine as well as for research projects. However, their isolation via density gradient centrifugation is still timeconsuming. When samples are taken beyond usual laboratory handling times, it may sometimes be necessary to pause the isolation process. Our aim was to evaluate the impact of delays up to 48 hours after the density gradient centrifugation on PBMC yield, purity and viability.

\section{Methods:}

PBMCs were isolated from samples of 20 donors, either with BD Vacutainer CPT tubes (CPT) or with the standard Ficoll method. Isolation was paused after initial density gradient centrifugation for 0, 24, or 48 hours. PBMC yield, purity and viability were compared.

\section{Results:}

The yield did not change significantly over time when CPT were used (55\%/52\%/47\%), but did after isolation with the standard method $(62 \% / 40 \%[\mathrm{p}<0.0001] / 53 \%[\mathrm{p}<0.01])$. Purity was only affected if CPT were used $(95 \% / 93 \%[\mathrm{p}=$ n.s. $/ 92 \%[\mathrm{p}<0.05]$ vs. $97 \%$ for all time points with standard method). Whereas viable PBMCs decreased steadily for CPT isolates $(62 \% / 51 \%[\mathrm{p}<0.001] / 36 \%[\mathrm{p}<0.0001])$, after standard Ficoll gradient isolation, cell apoptosis was more pronounced already after $24 \mathrm{~h}$ delay, and viability did not further decrease after $48 \mathrm{~h}$ $(64 \% / 44 \%[\mathrm{p}<0.0001] / 40 \%[\mathrm{p}<0.0001])$.

Conclusions:

In conclusion, our data suggests that post-centrifugation delays of up to $48 \mathrm{~h}$ might have only a minor effect on cell yield and purity. However, at the same time, a relevant decrease in cell 
medRxiv preprint doi: https://doi.org/10.1101/2022.01.02.22268625; this version posted January 3, 2022. The copyright holder for this preprint (which was not certified by peer review) is the author/funder, who has granted medRxiv a license to display the preprint in perpetuity.

All rights reserved. No reuse allowed without permission.

viability was observed, which could be partially compensated by the use of CPT if the isolation was resumed latest the day after blood withdrawal.

Keywords

PBMC; isolation; post-centrifugation delays; biobank; yield; purity; viability 
medRxiv preprint doi: https://doi.org/10.1101/2022.01.02.22268625; this version posted January 3, 2022. The copyright holder for this preprint (which was not certified by peer review) is the author/funder, who has granted medRxiv a license to display the preprint in perpetuity.

All rights reserved. No reuse allowed without permission.

\section{Introduction}

Peripheral blood mononuclear cells (PBMCs) are employed to investigate a broad range of diagnostic and research-related questions (1-4). The cells, which represent a diverse fraction of white blood cells including lymphocytes and monocytes, are usually separated in a density gradient (5). This step is time consuming, as it comprises the density gradient centrifugation, which is usually performed with low a- and deceleration, as well as several washing and preservation steps.

The original method included the layering of diluted, anticoagulated whole blood on density fluids, as e.g. Ficoll or Percoll $(6,7)$. Standardization and simplification efforts lead to the development of specific tubes, which - besides the density fluid - contain physical barriers that separate the PBMCs from other cellular blood components after centrifugation. In BD Vacutainer® Cell preparation tubes (CPT; Becton Dickinson, Franklin Lakes, USA), blood can be drawn directly, hence, no additional layering is necessary (8).

As mentioned above, the isolation of PBMCs is despite all standardization still time consuming and should be performed soon after blood withdrawal (9). Biobanks, which are facilities that specialize in the handling, storage, and distribution of biomaterials and related data, often receive samples for PBMC isolation throughout the day if some of their collections include viable cells. However, PBMC isolations of samples that are received later in the day can sometimes not be completed on the same day without working overtime. Manufacturers of isolation tubes recommend in this case to perform the density centrifugation step only and to continue with the washing steps at a later time point. Unfortunately, no data is so far available on the impact of this approach on the yield, the purity and the viability of PBMCs. 
medRxiv preprint doi: https://doi.org/10.1101/2022.01.02.22268625; this version posted January 3, 2022. The copyright holder for this preprint (which was not certified by peer review) is the author/funder, who has granted medRxiv a license to display the preprint in perpetuity.

All rights reserved. No reuse allowed without permission.

We, therefore, aimed to investigate the impact of delays up to 48 hours after the density gradient centrifugation step on PBMC quality. PBMCs were either isolated with CPT or, as a control, by standard Ficoll layering. Moreover, we evaluated the effect of different storage temperatures during these delays.

\section{Methods}

\section{Study design and participants}

Blood of 20 participants of the MedUni Wien Biobank "Healthy Donor Cohort" was included into this prospective method evaluation study. Inclusion criteria were an age $\geq 18$ years and willingness to give written informed consent, whereas insufficient biomaterial would have led to exclusion from the study. All donors provided written informed consent (ethics committee No. 404/2012). The study protocol is compliant with the Declaration of Helsinki and was reviewed and approved by the ethics committee of the Medical University of Vienna (No. 1022/2021). All samples were processed and stored by the MedUni Wien Biobank, a central facility with certified quality management (ISO 9001:2015) (10).

In brief, each participant donated $49 \mathrm{~mL}$ of blood. $1 \mathrm{~mL}$ was drawn in EDTA-tubes and used to perform a total blood count, 24mL were collected in 3 BD Vacutainer CPT tubes (Becton Dickinson, Franklin Lakes, USA), and the remaining $24 \mathrm{~mL}$ in 3 lithium heparine tubes (Greiner Bio-One, Kremsmuenster, Austria) for later PBMC isolation. The first isolation step (densitiy gradient centrifugation) was performed within one hour after blood collection. Then, one tube was used for each patient and isolation method to wash, aliquot and store cells either immediately (0h), after a $24 \mathrm{~h}$ or an $48 \mathrm{~h}$ delay, were cells were kept on $2-10^{\circ} \mathrm{C}$. For five 5 donors, drawn CPT tubes were kept on $2-10^{\circ} \mathrm{C}$ and on room temperature after the density gradient centrifugation step 
medRxiv preprint doi: https://doi.org/10.1101/2022.01.02.22268625; this version posted January 3, 2022. The copyright holder for this preprint (which was not certified by peer review) is the author/funder, who has granted medRxiv a license to display the preprint in perpetuity.

All rights reserved. No reuse allowed without permission.

to exclude a possible influence of post-centrifugation storage temperatures. A flow chart is presented in figure 1.

\section{Blood withdrawal and PBMC isolation}

Blood was drawn either directly into cell preparation tubes (CPT) or in lithium heparine tubes for Ficoll density gradient centrifugation. An additional small amount was used for a total blood count on an XN-2000 Hematology Analyzer (Sysmex, Kobe, Japan).

CPT tubes were centrifuged at $1,800 x g$ for 20 minutes at room temperature. For isolation according to a standard Ficoll density gradient centrifugation protocol, blood was diluted 1:2 in phosphate buffered saline (PBS; Carl Roth, Karlsruhe, Germany) and centrifuged at 863xg for 20 minutes at room temperature, without a fast start and a break. The cell layer was transferred to a sterile $15 \mathrm{~mL}$ tube and $10 \mathrm{~mL}$ of PBS was added. The washing steps described below were performed either immediately, after $24 \mathrm{~h}$ or after $48 \mathrm{~h}$. For the latter two time points, CPT were meanwhile stored at $2-8^{\circ} \mathrm{C}$ as recommended by the manufacturer.

If this has not already been done yet (CPT), cells were transferred to a sterile $15 \mathrm{~mL}$ tube and washed twice with at $311 \mathrm{xg}, 15 \mathrm{~min}$, room temperature. After the washing steps, cells were reconstituted in a freezing medium consisting of 70\% Iscove's Modified Dulbecco's Media inclusive Gentamycin (IMDM; Gibco, Grand Island, USA), 20\% fetal bovine serum (PanBiotech, Aidenbach, Germany) and 10\% dimethyl sulfoxide (DMSO; Carl Roth). A small portion of each isolate was used for the assessment of yield and purity. The remaining cell solution was transferred to cryovials which were slowly frozen for 48 hours in Mr. Frosty containers (Thermo Scientific, Waltham, USA) at $<-70^{\circ} \mathrm{C}$ and then moved to $\mathrm{LN}_{2}$ until viability assessment. 
medRxiv preprint doi: https://doi.org/10.1101/2022.01.02.22268625; this version posted January 3, 2022. The copyright holder for this preprint (which was not certified by peer review) is the author/funder, who has granted medRxiv a license to display the preprint in perpetuity.

All rights reserved. No reuse allowed without permission.

\section{Assessment of yield and purity}

As described above, total cell counts were performed on both the whole blood samples, as well as the final cell isolates of each donor. Yield was defined as the proportion of the isolated PBMCs (lymphocytes and monocytes) counted before freezing to the lymphocytes and monocytes that were present in the $8 \mathrm{~mL}$ of whole blood used: yield $=\frac{(\text { lymphocytes }+ \text { monocytes })_{\text {isolate }}}{(\text { lymphocytes }+ \text { monocytes })_{8 m L} \text { whole blood }}$. Purity was defined as the proportion of PBMCs to all leukocytes counted after isolation:

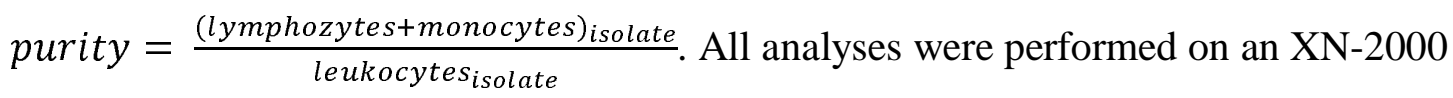
Hematology Analyzer (Sysmex).

\section{Viability staining}

Cryovials were taken from $\mathrm{LN}_{2}$ and thawed at room temperature. Then, samples were centrifuged at $300 \mathrm{xg}$ for 10 minutes at room temperature. After discarding the freezing media, cells were washed with 10mL HBSS (Gibco) and cell viability was assessed using a commercially available Annexin V Apoptosis Detection kit (Thermo Scientific). In brief, cells were washed once with $2 \mathrm{~mL}$ of $1 \mathrm{x}$ Binding buffer at $330 \mathrm{xg}$ for 10 minutes, room temperature. The cell pellets were then reconstituted in $100 \mu \mathrm{L}$ Binding Buffer $+2 \mu \mathrm{L}$ Annexin V APC. After an incubation step (15 minutes, room temperature, light protected), cells were again washed with $1 \mathrm{~mL} 1 \mathrm{x}$ Binding Buffer. Subsequently, $100 \mu \mathrm{L}$ Binding Buffer $+1 \mu \mathrm{L}$ propidium iodide were added to the cell pellets. Flow cytometry was performed on a BD FACSCanto II and results were analysed using the FACSDiva software (Becton Dickinson). As apoptotic cells start to incorporate Annexin V and, at a later stage, also propidium iodide, only cells that were both Annexin V and propidium iodide negative were considered viable. 
medRxiv preprint doi: https://doi.org/10.1101/2022.01.02.22268625; this version posted January 3, 2022. The copyright holder for this preprint (which was not certified by peer review) is the author/funder, who has granted medRxiv a license to display the preprint in perpetuity.

All rights reserved. No reuse allowed without permission.

\section{Statistical analysis}

If not otherwise indicated, continuous data are given by means \pm standard deviation. Main effects and the interaction of post-centrifugation delays and isolation methods (CPT vs. Ficoll) were evaluated by two-way repeated-measures ANOVAs with two within-subject variables. Post-hoc comparisons were performed according to Sidak. Paired data with groups sizes $\leq 10$ were compared by Wilcoxon tests. Results with p-values <0.05 were considered significant. All calculations were done with SPSS 23.0 (IBM, Armonk, USA) and graphs were drawn using GraphPad 7 (Graph Pad Inc., La Jolla, USA).

\section{Results}

\section{Impact of isolation delays on PBMC yield}

As described above, PBMCs from 20 healthy donors were either isolated using CPT or by a standard Ficoll density gradient centrifugation protocol, whereby isolation was paused for 0h, $24 \mathrm{~h}$ or $48 \mathrm{~h}$, respectively, after the initial centrifugation step. After extraction, the PBMC yield was determined.

For isolates for which extraction was completed on the day of blood withdrawal (0h delay), mean yields were $55 \pm 17 \%$ for CPT and $62 \pm 9 \%$ after standard Ficoll isolation. $24 \mathrm{~h} / 48 \mathrm{hs}$ delay after the first centrifugation step reduced the yield to $52 \pm 12 \% / 40 \pm 20 \%$ in CPT and to $47 \pm 11 \% / 53 \pm 10 \%$ applying Ficoll layering. A two-way repeated-measures ANOVA with two within-subject factors (delay and tube type) revealed a significant main effect for the isolation delay $\left(\mathrm{F}=11.8, \mathrm{df}_{1}=2\right.$, $\left.\mathrm{df}_{2}=38, \mathrm{p}<0.001\right)$ and a significant interaction delay $\mathrm{x}$ tube type $\left(\mathrm{F}=3,6, \mathrm{df}_{1}=2, \mathrm{df}_{2}=38, \mathrm{p}=0.036\right)$, indicating a different effect of isolation delays on both methods. In Sidak-corrected pair-wise comparisons, only the differences between isolates derived from different delays during Ficoll gradient centrifugation remained statistically significant. 
medRxiv preprint doi: https://doi.org/10.1101/2022.01.02.22268625; this version posted January 3, 2022. The copyright holder for this preprint (which was not certified by peer review) is the author/funder, who has granted medRxiv a license to display the preprint in perpetuity.

All rights reserved. No reuse allowed without permission.

To visualize the deviations resulting from an isolation delay more clearly, the yields from the delayed isolations were subsequently presented as a percentage of the yields of the undelayed isolation (Fig. 1a). For CPT, PBMC yields did not significantly decline over time, although a considerable variability was recorded (ranges after 24h/48h delay: 26-213\%/10-194\% compared to Oh delay). After standard Ficoll gradient isolation, in contrast, PBMC yields were significantly lower after both $24 \mathrm{~h}(76 \pm 15 \%)$ and $48 \mathrm{~h}(86 \pm 17 \%)$ delay when compared to baseline.

Hence, it appears as if delays in isolation protocols for up to 48 hours have a less significant impact when CPT are used. In the next step, the effect on the purity of PBMC isolates was examined.

\section{Impact of isolation delays on PBMC purity}

For the present study, PBMC purity was defined as the share of monocytes and lymphocytes in all isolated leukocytes. Mean purities were above $90 \%$ for all isolates (0h/24h/48h, CPT: $95 \pm 3 \% / 93 \pm 6 \% / 92 \pm 6 \%$, Ficoll: $97 \pm 1 \% / 97 \pm 2 \% / 97 \pm 1 \%)$. In a two-way repeated-measures ANOVA, the isolation method (CPT or Ficoll) presented with a significant main effect $(\mathrm{F}=11.3$, $\mathrm{df}_{1}=1, \mathrm{df}_{2}=19, \mathrm{p}=0.003$ ), indicating a purer cell isolate after the Ficoll method (difference, mean \pm SEM: $-4 \pm 1 \%)$. A significant interaction isolation method $\mathrm{x}$ delay $\left(\mathrm{F}=5.2, \mathrm{df}_{1}=2, \mathrm{df}_{2}=38\right.$, $\mathrm{p}=0.10$ ) also suggests a difference in the effect of delays for the individual isolation methods. However, post hoc Sidak-corrected tests did not produce any statistically significant results. Differences from baseline purities (set 100\%) were plotted for both isolation methods, and again, results from CPT tubes presented with greater variability (ranges after 24h/48h delay for CPT: 85-103\%/84-104\% and for Ficoll 97-104\%/97-103\%, both compared to 0h). However, only the purity after a $48 \mathrm{~h}$ delay in CPT tube isolation significantly differed from the purity of the undelayed isolate (Fig. 1b). 
medRxiv preprint doi: https://doi.org/10.1101/2022.01.02.22268625; this version posted January 3, 2022. The copyright holder for this preprint (which was not certified by peer review) is the author/funder, who has granted medRxiv a license to display the preprint in perpetuity.

All rights reserved. No reuse allowed without permission.

These results suggest that PBMC purity, which was significantly higher after standard Ficoll gradient centrifugation than with CPT tubes, was only marginally affected by delayed isolations.

Finally, cell viability was assessed.

\section{Impact of isolation delays on PBMC viability}

PBMC viability was assessed after storage in $\mathrm{LN}_{2}$ using a commercially available Annexin V/propidium iodide staining kit. Only cells without propidium iodide and Annexin V signals in flow cytometry were classified as viable. In the two-way repeated-measures ANOVA, the frequency of both Annexin V and propidium iodide negative, i.e., viable, cells declined with increasing delay $\left(\mathrm{F}=70.9, \mathrm{df}_{1}=2, \mathrm{df}_{2}=38, \mathrm{p}<0.0001\right)$ from (mean $\left.\pm \mathrm{SEM}\right) 63 \pm 2 \%$ (0h) to $47 \pm 3 \%$ (24h) and $38 \pm 3 \%(48 \mathrm{~h})$. However, besides this significant main effect, the interaction isolation method $\mathrm{x}$ delay was significant as well, indicating a different impact of delays on the isolation methods $\left(\mathrm{F}=6.8, \mathrm{df}_{1}=2, \mathrm{df}_{2}=38, \mathrm{p}=0.003\right)$. Whereas viable PBMCs decreased steadily for CPT isolates, after standard Ficoll gradient isolation, cell apoptosis was more pronounced already after 24h delay, and viability did not further decrease after $48 \mathrm{~h}$. In CPT tubes, only $83 \pm 17 \% / 57 \pm 22 \%$ of the PBMCs that were viable in undelayed samples lacked apoptosis signals after $24 \mathrm{~h} / 48 \mathrm{~h}$. After standard Ficoll gradient centrifugation, cell viabilities compared to the undelayed samples were $67 \pm 20 \% / 60 \pm 20 \%$ after $24 \mathrm{~h} / 48 \mathrm{~h}$ (Fig. 1c).

Taken together, our results suggest that despite minor reductions in cell yield and purity, delays during PBMC isolations considerably affect PBMC viability.

\section{The influence of storage temperature after density gradient centrifugation}

However, several protocols suggest to keep CPT tubes rather on room temperature instead of 2$10^{\circ} \mathrm{C}$ to prevent platelet activation and apoptosis. To quantify the influence of storage 
medRxiv preprint doi: https://doi.org/10.1101/2022.01.02.22268625; this version posted January 3, 2022. The copyright holder for this preprint (which was not certified by peer review) is the author/funder, who has granted medRxiv a license to display the preprint in perpetuity.

All rights reserved. No reuse allowed without permission.

temperature after the first centrifugation, we repeated the experiment with sample material from ten (yield/purity) or five (viability) different samples using only CPT tubes.

In Fig. 2, yield represents the proportion of PBMCs that could be successfully isolated from the primary material (a), purity represents the proportion of PBMCs within the isolate (b), and viability represents the proportion without Annexin V/propidium iodide uptake (c). In Wilcoxon analysis, samples kept at room temperature presented with a higher yield $(24 \mathrm{~h}:+0.16, \mathrm{p}=0.013$; 48h: $+0.14, \mathrm{p}=0.037$ ), but with a lower purity, especially after the $24 \mathrm{~h}$ centrifugation delay (24h: 0.01, $\mathrm{p}=0.017 ; 48 \mathrm{~h}:-0.01, \mathrm{p}=0.093)$. However, storage at $2-10^{\circ} \mathrm{C}$ was not inferior to room temperature at $24 \mathrm{~h}(+0.01, \mathrm{p}=0.893)$ and resulted in an even better viability after $48 \mathrm{~h}(+0.28$, $\mathrm{p}=0.043)$.

\section{Discussion}

Post-centrifugation delays during the time-consuming PBMC isolation are often inevitable in preanalytical facilities that do not operate on a $24 / 7$ basis. Although delays up to $48 \mathrm{~h}$ might not relevantly reduce cell yield if special cell preparation tubes are used, cell viability is significantly affected. To the best of our knowledge, this phenomenon has not been systematically reported before.

There is certain evidence that the time to the first centrifugation step is critical regarding cell yield, purity and viability. PBMC counts after a pre-isolation delay of 30 hours when compared to cells extracted within the first day after blood withdrawal (11). Regarding purity, an 84-fold increase in granulocyte contamination was reported when whole blood was refridgerated for 2226 hours before PBMCs were isolated (12). Cell viability was shown to be relevantly decreased if isolation started 24 hours after blood withdrawal in both CPT and Ficoll to tubes, although it has to be mentioned that only samples from three donors were included (13). 
medRxiv preprint doi: https://doi.org/10.1101/2022.01.02.22268625; this version posted January 3, 2022. The copyright holder for this preprint (which was not certified by peer review) is the author/funder, who has granted medRxiv a license to display the preprint in perpetuity.

All rights reserved. No reuse allowed without permission.

Reports regarding the effect of post-centrifugation delays can be hardly found. A recent review presented data of only three samples (9), which are, indeed, in line with our observations.

Our experimental setup differed regarding the temperature, at which samples were stored after centrifugation. Although protocols suggest to keep samples at room temperature, we decided to refridgerate centrifuged $\mathrm{CPT}$ tubes at $2-10^{\circ} \mathrm{C}$ during the post-centrifugation delay to ensure comparability with standard-Ficoll preparations, which were refridgerated as well. This was done in order to curb the cell metabolism, as Ficoll poses a potentially toxic environment for cells (14) and alters their electrolyte and trace element composition (15). To assess, whether our findings were solely attributable to the post-centrifugation storage temperature, we compared samples stored at room temperature to those stored at $4{ }^{\circ} \mathrm{C}$ after the first centrifugation step. Although the latter showed a slightly lower yield, they were significantly more pure and had a lower platelet contamination. Moreover, storage at $2-10^{\circ} \mathrm{C}$ instead of room temperature did not seem to further impair viability - in fact, the proportion of viable cells after an $48 \mathrm{~h}$ centrifugation delay was significantly higher in refrigerated samples (Fig. 2).

In conclusion, our data suggests that post-centrifugation delays of up to $48 \mathrm{~h}$, as permitted by manufacturers of PBMC preparation tubes, might have only a minor effect on cell yield and purity. However, at the same time, a relevant decrease in cell viability was observed, which could be partially compensated by the use of CPT if the isolation was resumed latest the day after blood withdrawal. Thus, it appears that both biobankers and researchers must be aware that the logistic advantage of delaying PBMC isolations after the density gradient centrifugation might come at the cost of cell viability. 


\section{Acknowledgments}

We thank all participants for their valuable donations. The MedUni Wien Biobank is part of the Austrian biobanking consortium BBMRI.at.

\section{Research funding}

None.

\section{Competing interests}

Authors state no conflict of interest.

\section{References}

1. Kratzer B, Trapin D, Ettel P, Körmöczi U, Rottal A, Tuppy F, et al. Immunological imprint of COVID-19 on human peripheral blood leukocyte populations. Allergy. $2021 ; 76(3): 751-65$.

2. Mallone R, Mannering SI, Brooks-Worrell BM, Durinovic-Belló I, Cilio CM, Wong FS, et al. Isolation and preservation of peripheral blood mononuclear cells for analysis of islet antigen-reactive $\mathrm{T}$ cell responses: position statement of the T-Cell Workshop Committee of the Immunology of Diabetes Society. Clin Exp Immunol. 2011;163(1):33-49.

3. Arosio B, D'Addario C, Gussago C, Casati M, Tedone E, Ferri E, et al. Peripheral blood mononuclear cells as a laboratory to study dementia in the elderly. Biomed Res Int. 2014;2014:169203.

4. Acosta Davila JA, Hernandez De Los Rios A. An Overview of Peripheral Blood Mononuclear Cells as a Model for Immunological Research of Toxoplasma gondii and Other Apicomplexan Parasites. Front Cell Infect Microbiol. 2019;9:24. 
medRxiv preprint doi: https://doi.org/10.1101/2022.01.02.22268625; this version posted January 3, 2022. The copyright holder for this preprint (which was not certified by peer review) is the author/funder, who has granted medRxiv a license to display the preprint in perpetuity. All rights reserved. No reuse allowed without permission.

5. Fuss IJ, Kanof ME, Smith PD, Zola H. Isolation of whole mononuclear cells from peripheral blood and cord blood. Curr Protoc Immunol. 2009; Chapter 7:Unit7.1.

6. Ulmer A, Scholz W, Ernst M, Brandt E, Flad H-D. Isolation and subfractionation of human peripheral blood mononuclear cells (PBMC) by density gradient centrifugation on Percoll. Immunobiology. 1984;166(3):238-50.

7. Kanof ME, Smith PD, Zola H. Isolation of whole mononuclear cells from peripheral blood and cord blood. Current Protocols in Immunology. 1996;19(1):7.1. -7.1. 7.

8. Puleo A, Carroll C, Maecker HT, Gupta R. Isolation of Peripheral Blood Mononuclear Cells Using Vacutainer(®) Cellular Preparation Tubes (CPT(TM)). Bio Protoc. 2017;7(2):e2103.

9. Betsou F, Gaignaux A, Ammerlaan W, Norris PJ, Stone M. Biospecimen Science of Blood for Peripheral Blood Mononuclear Cell (PBMC) Functional Applications. Current Pathobiology Reports. 2019;7(2):17-27.

10. Haslacher H, Gerner M, Hofer P, Jurkowitsch A, Hainfellner J, Kain R, et al. Usage Data and Scientific Impact of the Prospectively Established Fluid Bioresources at the Hospital-Based MedUni Wien Biobank. Biopreserv Biobank. 2018;16(6):477-82.

11. Palmirotta R, De Marchis ML, Ludovici G, Leone B, Savonarola A, Ialongo C, et al. Impact of preanalytical handling and timing for peripheral blood mononuclear cells isolation and RNA studies: the experience of the Interinstitutional Multidisciplinary BioBank (BioBIM). Int J Biol Markers. 2012;27(2):e90-8.

12. McKenna KC, Beatty KM, Vicetti Miguel R, Bilonick RA. Delayed processing of blood increases the frequency of activated CD11b+CD15+ granulocytes which inhibit T cell function. $\mathrm{J}$ Immunol Methods. 2009;341(1-2):68-75. 
medRxiv preprint doi: https://doi.org/10.1101/2022.01.02.22268625; this version posted January 3, 2022. The copyright holder for this preprint (which was not certified by peer review) is the author/funder, who has granted medRxiv a license to display the preprint in perpetuity. All rights reserved. No reuse allowed without permission.

13. Hamot G, Ammerlaan W, Mathay C, Kofanova O, Betsou F. Method validation for automated isolation of viable peripheral blood mononuclear cells. Biopreserv Biobank. 2015;13(3):152-63.

14. Pösel C, Möller K, Fröhlich W, Schulz I, Boltze J, Wagner DC. Density gradient centrifugation compromises bone marrow mononuclear cell yield. PLoS One. 2012;7(12):e50293.

15. Lu Y, Ahmed S, Harari F, Vahter M. Impact of Ficoll density gradient centrifugation on major and trace element concentrations in erythrocytes and blood plasma. J Trace Elem Med Biol. 2015;29:249-54. 
medRxiv preprint doi: https://doi.org/10.1101/2022.01.02.22268625; this version posted January 3, 2022. The copyright holder for this preprint (which was not certified by peer review) is the author/funder, who has granted medRxiv a license to display the preprint in perpetuity. All rights reserved. No reuse allowed without permission.

\section{Figure Legends}

Fig. 1: PBMC yield (a), purity (b), and viability (c) measured after a 24 h or 48 h delay in PBMC isolation protocols were compared to undelayed isolates $(0 h)$. Red/black asterisks indicate significant deviations at the respective delay $(24 h, 48 h)$ from the undelayed sample (Oh) for CPT/standard Ficoll gradient centrifugation protocols. Blue asterisks mark the differences between isolation methods at a given delay. $M \pm S D . .$. mean \pm standard deviation; $* \ldots p<0.05$, $* * \ldots p<0.01, * * * \ldots p<0.001, * * * * \ldots p<0.0001$, n.s.... not significant.

Fig. 2: Differences in yield ( $n=10$ samples per group), purity ( $n=10$ samples per group) and viability ( $n=5$ samples per group) after $24 \mathrm{~h}$ and $48 \mathrm{~h}$ post-centrifugation delays in samples stored at room temperature ( $R T$, filled circles) vs. $2-10^{\circ} \mathrm{C}$ (filled squares). 
a)

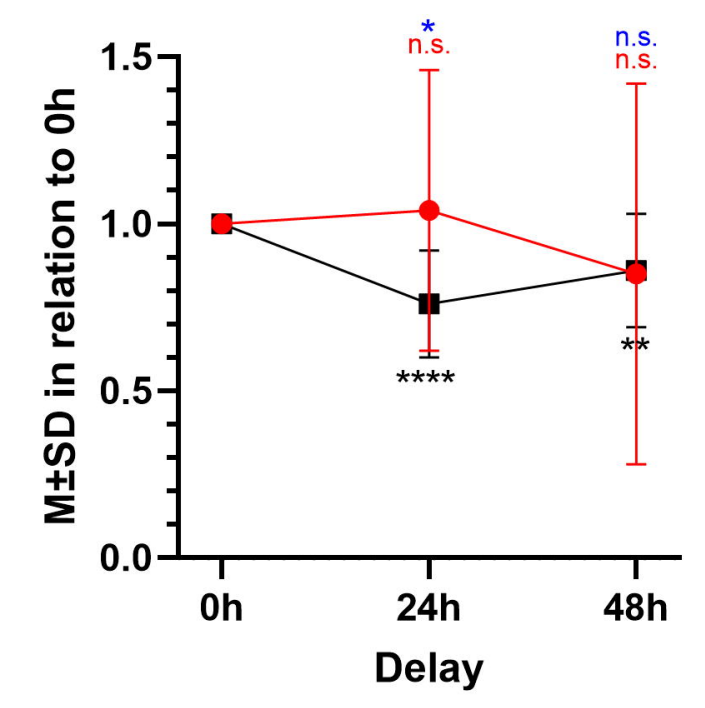

b)

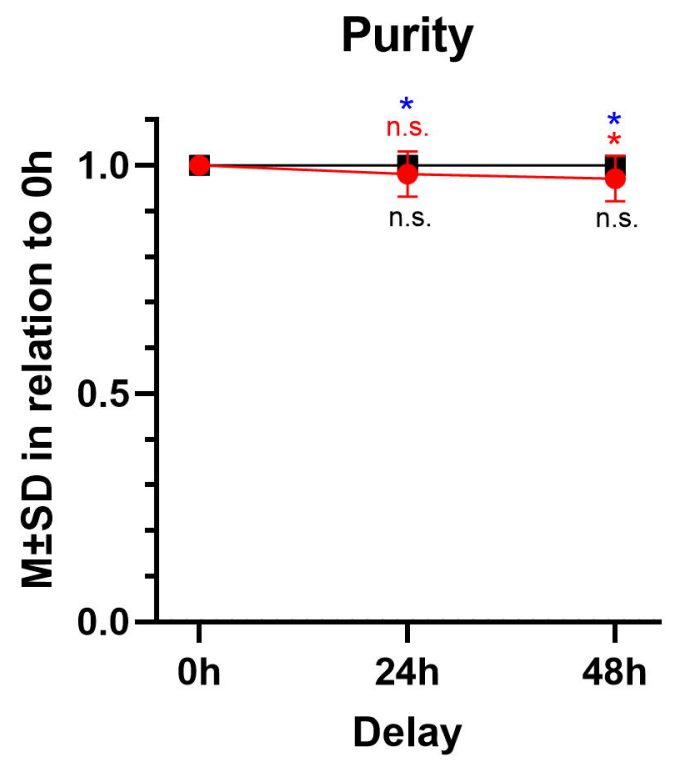

c)

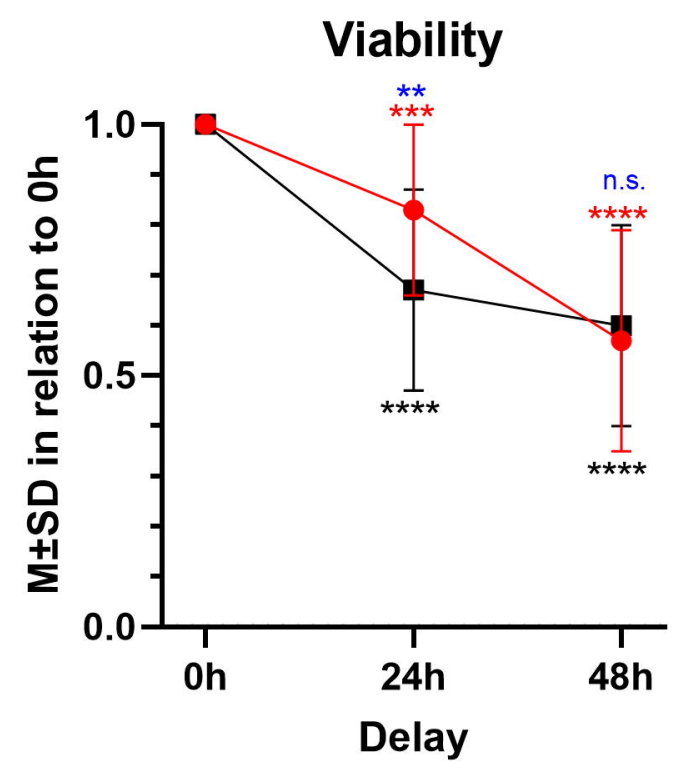

-- CPT

- Ficoll 
Yield

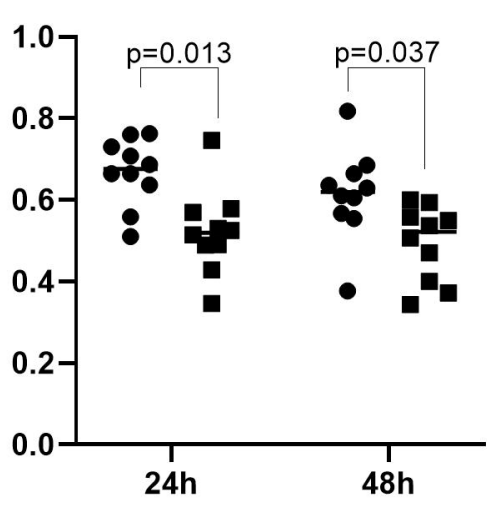

\section{Purity}

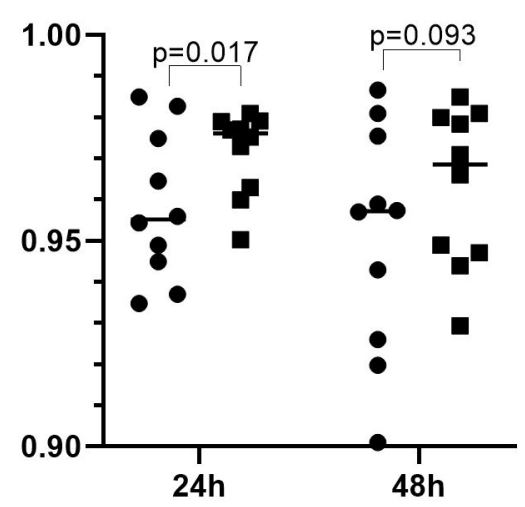

\section{Viability}

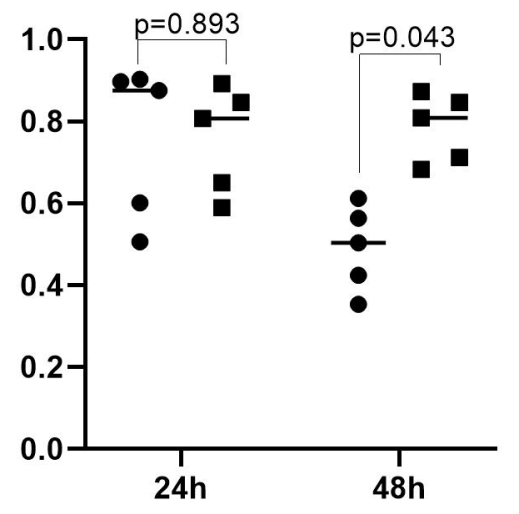

- RT

- $2-10^{\circ} \mathrm{C}$ 